\title{
Influence of Obesity on Bone Density in Postmenopausal Women
}

\begin{abstract}
Objective: To evaluate the influence of obesity, age, and years since menopause on bone density. Methods: A retrospective analysis of bone mineral density (BMD) obtained from 588 women, 41 to 60 years, previously menopaused (1-10 years before). Results: Positive influence of obesity was confirmed by the significant differences in BMD at lumbar spine, femoral neck (FN), and trochanter (TR) between the groups $(p<0.01)$. Age and years since menopause (YSM) were negatively correlated with BMD at all sites $(p=0.000)$. Comparing patients within 1 to $<6$ YSM versus 6 to 10 YSM, BMD was higher in the former at LS and FN $(p<0.005)$, despite the higher $\mathrm{BMI}$ in the older group $(p=0.01)$. Obese patients had a lower prevalence of osteoporosis at LS and FN $(p=0.009)$. Regression analysis identified BMI as the strongest determinant of FN and TR BMD, while YSM was the strongest determinant of LS BMD. Conclusion: The protective effect of obesity is overtaken by age and estradiol deficiency. We recommend that even obese postmenopausal women should be screened for osteoporosis. (Arq Bras Endocrinol Metab 2007;51/6:943-949)
\end{abstract}

Keywords: Menopause; Estrogens; Obesity; Bone density; Osteoporosis

\section{RESUMO}

Influência da Obesidade na Densidade Óssea em Mulheres na PósMenopausa.

Objetivo: Avaliar a influência de obesidade, idade e anos de menopausa sobre a densidade óssea. Métodos: Análise retrospectiva da densidade mineral óssea (DMO) obtida em 588 mulheres de 41 a 60 anos, já menopausadas (1-10 anos antes). Resultados: $A$ influência positiva da obesidade foi confirmada através de diferenças significativas da DMO entre os grupos na coluna lombar (CL), colo de fêmur (CF) e trocânter (TR) $(p<0,01)$. Idade e anos desde a menopausa (ADM) foram correlacionados negativamente com DMO em todos os sítios $(p=0,000)$. Comparando-se pacientes entre 1 e < 6 ADM vs 6 e 10 AMD, a DMO foi maior no primeiro grupo na CL e CF $(p<0,005)$, apesar de maior DMO no grupo de mais idade $(p=0,01)$. Pacientes obesas tiveram uma prevalência mais baixa de osteoporose na CL e CF $(p=0,009)$. Análise de regressão identificou o IMC como o determinante mais forte da DMO de CF e trocânter, enquanto a ADM foi o determinante mais forte da DMO na CL. Conclusão: $O$ efeito protetor da obesidade é sobrepujado pela deficiência de estradiol. Recomendamos que mesmo mulheres obesas na pós-menopausa devam ser examinadas para osteoporose. (Arq Bras Endocrinol Metab 2007;51/6:943-949)

Descritores: Menopausa; Estrógenos; Obesidade; Densidade óssea; Osteoporose artigo original

\author{
Henyse G. Valente da Silva \\ LAURA M.C. MENDONÇA \\ FLÁVIA L. CONCEIÇÃO \\ SILVIA E.V. ZAHAR \\ MARIA LUCIA F. FARIAS \\ Division of Endocrinology (HGVS, \\ FLC \& MLLF), Rheumathology \\ (LMCM), and Gynecology \\ (SEVZ), HUCFF, Federal University \\ of Rio de Janeiro, RJ.
}

Recebido em 06/09/06

Revisado em 16/01/07

Aceito em 06/03/07 
$\mathrm{O}$ STEOPOROSIS IS A SYSTEMIC skeletal disease in which the amount of normally mineralized bone is reduced and the microarchitectural bone tissue, mainly trabecular elements, deteriorated. This disturbance leads to an increase in fracture risk, even with minimum trauma (1). The clinical significance of osteoporosis is currently expressed by the frequency of hip fracture, implying great morbidity and high cost for health services.

It is estimated that osteoporosis fracture cost, in the USA, is about US\$ 10 billion annually for a population of 250 million people $(2,3)$. According to the American National Osteoporosis Foundation (NOF), based on 2000 census data, osteoporosis and low bone mass affect 44 million people that represent $55 \%$ of people aged 50 and older. From this total $80 \%$ are women. They estimated that in 2020 this number will raise to more than 60 million (4).

Bone density is the major measurable determinant of the risk for osteoporotic fracture. Bone mass increases during childhood and adolescence, peaks in the third or fourth decade of life, remains stable for some years during menacme and declines progressively thereafter, with a sharp acceleration of bone loss during the five to ten years after menopause, ranging from less than $1 \%$ to more than $5 \%$ per year $(1,5-12)$.

Obesity, defined as body mass index (BMI) between 25 and $39.9 \mathrm{Kg} / \mathrm{m}^{2}$, has a protective effect on bone $(13,14)$. Several mechanisms seem to be involved, such as the mechanical effect of increased weight bearing on muscle that stimulates bone formation (15), increased aromatization of androgen to estrogen in adipose tissue $(16,17)$, decreased sex-hormone binding globulin with an increase in free sex steroids (14), increased serum leptin $(18,19)$, increased synthesis of insulin-like growth factors in the liver and the skeleton, and also hyperinsulinemia and insulin resistance (20).

The purpose of this study was to evaluate the relationship between bone density and obesity in postmenopausal women.

\section{SUBJECTS AND METHODS}

\section{Study group}

A retrospective analysis of bone density data obtained from 588 postmenopausal women examined at a densitometric Clinic in Rio de Janeiro (Osteolab). Inclusion criteria were to be Caucasian, healthy, 41 to 60 years old and within 1 to 10 years after spontaneous menopause. The exclusion criteria were $\mathrm{BMI} \geq 40$ (severe obesity), history of chronic diseases, such as renal, hepatic, cardiac, rheumatic diseases, use of drugs that could interfere with bone mass, such as corticosteroids and antireabsortive drugs, hormonal replacement therapy or to smoke more than 10 units/day or alcohol user. All these statements were obtained by a questionnaire applied before the exam was done and answered by the patients themselves.

As it was a retrospective study, we based it on the World Medical Association Declaration of Helsinki, with Ethical Principles for Medical Research Involving Human Subjects.

\section{Data collection}

Anthropometric measures included weight (W), height $(\mathrm{H})$, and body mass index $(\mathrm{BMI})$ calculated as $\mathrm{W} / \mathrm{H}^{2}(21,22)$. Patients were divided in normal weighted $\left(18.5 \leq \mathrm{BMI}<24.9 \mathrm{Kg} / \mathrm{m}^{2}\right)$ and overweight or obese women $\left(25 \leq \mathrm{BMI}<40 \mathrm{Kg} / \mathrm{m}^{2}\right)$. We considered that any grade of excessive weight could be a protective factor for bone density. Patients were also divided according to the number of years since natural menopause (YSM) in two groups: 1 to 5 YSM and 6 tol0 YSM. This division was done because we have just a 10-year period after menopause. Smaller divisions seem not to improve our data.

\section{Bone densitometry}

Bone mineral density (BMD) was assessed by dual energy X-ray absorptiometry at the lumbar spine (LS) and hip (femoral neck and trochanter), using a Lunar DPX-L, Madison, Wisconsin, USA. The coefficient of variation $(\mathrm{CV})$ was $0.5 \%$ with Phanton and $2 \%$ in vivo evaluation. Accuracy and precision were, respectively, $1 \%$ and $2.5 \%(23)$.

\section{Medical ethics}

As a retrospective study, it was in accordance with the Helsinki Declaration.

\section{Statistics}

Statistical analysis was performed with SPSS software (version 10.0). Data were expressed as mean \pm SD. Groups were compared by Student's $t$ test. Chi square was used to analyze the frequency of osteopenia or osteoporosis in normal weighted and obese patients. Pearson simple linear regression and correlation analysis were used to evaluate the interrelationship between parameters. In addition, regression linear analysis was used to assess the association between bone density (dependent variable) and age, body mass index and years since menopause (independent variables). The correlation analysis was carried out in two stages. In 
the first stage, each explanatory variable was tested using the Pearson coefficient. Then, those variables that reached a significant association at the 5\% level were included in a multiple linear regression model. A $\mathrm{p}$-value less than 0.05 was accepted as significant for all analyses in the study.

\section{RESULTS}

Anthropometric data, time elapsed since menopause and bone density are shown in table $\mathrm{l}$. Age and years since menopause (YSM) were not significantly different between normal weighted and obese patients, but bone density was higher in obese patients in all sites evaluated.

Patients within $\mathrm{l}$ and $\leq 5$ years since menopause were younger, had a lower BMI but a higher BMD at the LS and FN than the group within $\geq 6$ to $10 \mathrm{YSM}$, as seen in table 2 .

Assuming lumbar spine and femoral neck as the most important areas of fracture risk, we compared normal weighted and obese patients according to the prevalence of normal bone density, osteopenia, and osteoporosis at both sites. Osteoporosis was significantly less frequent in obese women, as shown in figure 1 .

Correlation analysis confirmed the positive influence of obesity on bone mass and also showed a significant and negative influence of age and YSM, as shown in table 3 .

Regression analysis identified BMI as the most important determinant of bone density at femoral neck, while the time elapsed since menopause was the most important determinant of lumbar spine BMD.

Table 1. Comparisons of normal weighted and obese postmenopausal women according to anthropometric and densitometric data.

\begin{tabular}{lccc}
\hline Characteristics & $\begin{array}{c}\text { Normal weight } \\
\mathbf{n = 2 8 9}\end{array}$ & $\begin{array}{c}\text { Obese } \\
\mathbf{n = 2 9 9}\end{array}$ & p value \\
Age (years) & $53.9 \pm 4.0$ & $54.5 \pm 3.7$ & 0.071 \\
Weight $(\mathrm{Kg})$ & $56.5 \pm 5.2$ & $69.9 \pm 8.4$ & 0.000 \\
Height $(\mathrm{cm})$ & $157.8 \pm 5.8$ & $157.7 \pm 5.3$ & 0.841 \\
Body mass index $\left(\mathrm{Kg} / \mathrm{m}^{2}\right)$ & $22.7 \pm 1.5$ & $28.1 \pm 2.8$ & 0.000 \\
\hline Years since menopause & $4.8 \pm 2.7$ & $5.2 \pm 2.8$ & 0.070 \\
\hline Lumbar spine BMD $\left(\mathrm{g} / \mathrm{cm}^{2}\right)$ & $0.992 \pm 0.178$ & $1.031 \pm 0.168$ & 0.006 \\
\hline Femoral neck BMD $\left(\mathrm{g} / \mathrm{cm}^{2}\right)$ & $0.798 \pm 0.113$ & $0.853 \pm 0.110$ & 0.000 \\
\hline
\end{tabular}

Data are expressed as means \pm SD. BMD: bone mineral density.

Table 2. Differences in bone mineral density according to the time elapsed since menopause: 1 to $\leq 5$ years and $\geq 6$ to 10 years since menopause (YSM).

\begin{tabular}{lccc}
\hline Characteristics & $\begin{array}{c}\mathbf{1} \text { to } \leq \mathbf{5} \text { YSM } \\
\mathbf{n}=\mathbf{3 1 8}\end{array}$ & $\begin{array}{c}\mathbf{6 - 1 0} \text { YSM } \\
\mathbf{n}=\mathbf{2 7 0}\end{array}$ & $\boldsymbol{p}$ value \\
Age $(\mathrm{yrs})$ & $52 \pm 3.7$ & $56 \pm 3.2$ & 0.00001 \\
$\mathrm{BMI}\left(\mathrm{kg} / \mathrm{m}^{2}\right)$ & $25 \pm 3.5$ & $25.7 \pm 3.8$ & 0.01 \\
Lumbar spine BMD $\left(\mathrm{g} / \mathrm{cm}^{2}\right)$ & $1.051 \pm 0.151$ & $0.974 \pm 0.163$ & 0.0001 \\
Femoral neck BMD $\left(\mathrm{g} / \mathrm{cm}^{2}\right)$ & $0.843 \pm 0.121$ & $0.811 \pm 0.112$ & 0.004 \\
\hline
\end{tabular}

Data are expressed as means \pm SD. BMD: bone mineral density

Table 3. Pearson's coefficient (R) and significance level $(p)$, between body mass index (BMI), age, and years since menopause (YSM) with bone mineral density (BMD) in 588 postmenopausal women.

\begin{tabular}{lcccc} 
& \multicolumn{2}{c}{ Femoral neck BMD } & \multicolumn{2}{c}{ Lumbar spine BMD } \\
& $\mathbf{R}$ & $\boldsymbol{p}$ & $\mathbf{R}$ & $\boldsymbol{p}$ \\
BMI & 0.294 & 0.000 & 0.151 & 0.000 \\
Age & -0.158 & 0.000 & -0.201 & 0.000 \\
YSM & -0.160 & 0.000 & 0.278 & 0.000 \\
\hline
\end{tabular}




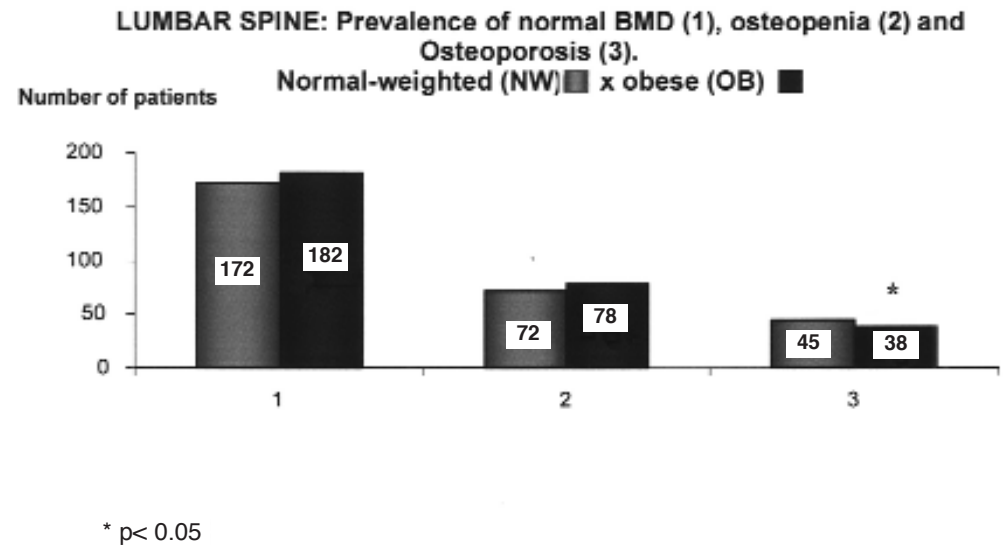

FEMORAL NECK: Prevalence of normal BMD (1), osteopenia (2) and Osteoporosis (3).

Normal-weighted (NW) $\square \times$ obese (OB)

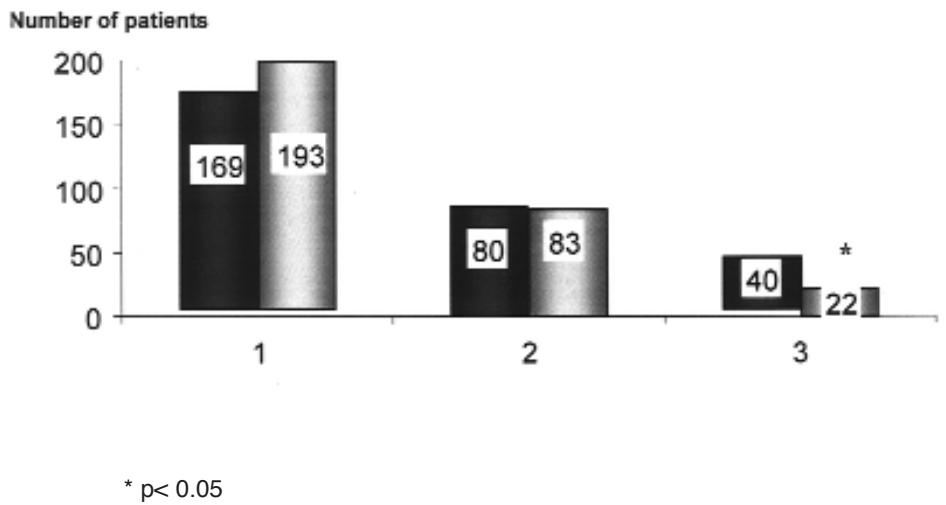

Figure 1. Number of postmenopausal women (absolute values) with normal BMD (1), osteopenia (2), and osteoporosis (3) at the lumbar spine and femoral neck, comparing the normal-weighted and the obese patients.

\section{DIscussion}

Menopause is associated with an imbalance in bone metabolism, and the first five to ten years after menopause is the period of higher bone turnover and bone loss $(24,25)$. Approximately $35 \%$ of postmenopausal women lose significant amounts of bone mineral during this period ("fast losers") and are at a higher risk for osteoporosis and fragility fractures later in life (26). The decline in ovarian estrogen production is the main determinant of this imbalance, but estradiol serum levels explain only a small proportion of inter individual variance of BMD and bone loss. Therefore, many other factors seem to be involved, such as age, lean and fat mass, exercise, race, smoke, and genetic factors.
Ribot and Albala $(27,14)$ previously described that obese women have higher bone mass after menopause than normal weighted age-matched women, especially at lumbar spine and femoral neck. In our cross-sectional study of 588 postmenopausal patients, we confirmed this influence as body mass index was positively correlated with bone density at all sites and the prevalence of osteoporosis was lower in the obese group.

The positive effect of body weight on bone is mediated by both lean mass and fat mass. Rico et al. studied the effect of soft tissue mass on skeletal loading in overweight and obese women, and found that this factor is the main determinant of bone mass, regardless of gonadal status (28). 
Muscular strength also influences skeletal loading. Physically exercising postmenopausal women have greater lean mass that explains the strong association between increased muscle mass and bone density. According to Blain et al., quadriceps strength explains a great part of the association between lean mass and BMD at the femoral neck, suggesting a specific effect of muscular strength on bone and an age-related decline of muscle strength in age-related bone loss in postmenopausal women (29).

Muscle mass or lean body mass were not evaluated in our study, but there were no athletes in the group. We thus suppose that the increase in body weight was mostly due to increased fat mass, as previously described by Frost et al. (23).

The positive effect of obesity on bone is multifactorial, as it is associated not only with the mechanical load as well as with the secretion of bone-active hormones from the pancreatic beta cell (insulin, amylin, and preptin), and the secretion of bone-active hormones such as estrogens and leptin from the adipocyte (30).

The secretion of bone-active hormones from the pancreatic beta cell is increased in obesity. Insulin and insulin-like growth factor can influence bone turnover as well as peripheral estrogen production in adipose tissue (31). Reid and Haffner $(32,33)$ demonstrated a positive correlation between bone density and fasting insulin level, emphasizing that hyperinsulinemia could be an osteogenic factor. Preptin and amylin are also hormones produced in pancreatic betacells. Amylin is a polypeptide that belongs to the family of calcitonin gene-related peptides, stimulates the proliferation of osteoblasts, inhibits bone resorption, and increases bone mass and bone density (34).

Another bone-active hormone linked to bone mass and obesity is an $o b$ gene product named Leptin, produced in adipocytes. It regulates feeding behavior and energy homeostasis with both neuroendocrine and reproductive effects (35) and acts on human marrow stromal cells to enhance differentiation to osteoblasts and to inhibit differentiation to adipocytes $(18,19)$. Both bone mass and serum leptin levels are increased in obesity, although the influence of leptin on bone is still a matter of debate. Some authors show a positive correlation $(30,31)$ while others show a negative one, both in female (36) and male patients (37).

Estrogen is another bone active hormone increased in obesity. Fat tissue converts androstenedione to estrone by aromatization and this corresponds to the principal source of estrogen in the postmenopausal female, rather than ovarian or adrenal secretion $(16,17)$. Cleland (38) showed that aromatase activity in adipose stromal cells increases as a function of age, being higher in postmenopausal than in premenopausal women. Thus, the increased estrogen production in obese postmenopausal women is due to a larger number of adipose cells and enhanced aromatase activity. These findings provide strong support for the view that increased synthesis of estrone in adipose tissue may be a contributing factor to bone mass in women passing through natural menopause. Furthermore, Nawata (16) demonstrated that the adrenal androgen DHEA is converted to estrone in osteoblasts by $\mathrm{P} 450$ aromatase, and this could also contribute to the maintenance of bone mass in the 6th to 7 th decade of life.

In postmenopausal women, increased bone turnover is associated with an increased risk of osteoporotic fracture independently of BMD (39). This risk is diminished in obese women as they seem to lose bone at a slower rate after menopause (40-42). As a consequence, obese postmenopausal women have less osteoporotic fractures, particularly hip fractures $(13,14,24,27)$.

We didn't forget that obesity can be associated with bone artrosis and that this factor can have a positive effect on BMD (43).

We observed that the prevalence of osteoporosis was lower in obese than in non-obese postmenopausal women, both at the lumbar spine and the femoral neck. This positive correlation between obesity and bone mass could be due to the influence of increased estrone and the mechanical load on skeleton (44).

We also demonstrated the negative effect of age and time elapsed since menopause on bone mass, as previously described by Becker, McClung, Ahlborg, and Szejnfeld (45-48). Our population within 6 to 10 years since menopause had a lower BMD either at the lumbar spine and femoral neck. It must be considered that these women were older and had higher BMI than the group with less hormonal deprivation. Therefore, the age-related decline of muscle strength and ovarian estrogen production should be considered important factors involved in osteoporosis, more important than the eventual increase in estrone production in adipose tissue.

We conclude that the protective effect of obesity is overtaken by age and years of estradiol deficiency. Our data lead us to recommend that all postmenopausal women should be screened for osteoporosis whether obese or not.

Once detected osteopenia or osteoporosis, adequate treatment should be instituted, which includes modifications in lifestyle such as exercise, calcium and vitamin D supplements and fall prevention, as well as anti resorption therapy when necessary. 


\section{ACKNOWLEDGEMENTS}

The authors wish to thank Dr. M.R. BenckeGonçalves, Dayse G.S. Campos and M. Santos for laboratory support.

\section{REFERENCES}

1. Anonymous. Consensus Development Conference. Diagnosis, prophylaxis and treatment of osteoporosis. Am J Med 1993; $94: 646-50$.

2. Connor EB. The economic and human cost of osteoporotic fracture. Am J Med 1995;98(2A):3S-7S.

3. King AB, Saag KG, Burge RT, Pisu M, Goel N. Fracture Reduction Affects Medicare Economics (FRAME): Impact of increased osteoporosis diagnosis and treatment. Osteoporos Int 2005;16(12):1545-57.

4. America's Bone Health: The state of osteoporosis and low bone mass in US. National Osteoporosis Foundation. Annual Report. Disponível em: <http:/www.nof.org/advocacy/prevalence>. Acessado em Outubro de 2005.

5. Bachrach LK. Bone mineralization in childhood and adolescence. Curr Opin Pediatr 1993;5(4):467-73.

6. Saggese G, Bertelloni S, Baroncelli Gl. Sex steroids and the acquisition of bone mass. Horm Res 1997;48(suppl. 5):65-71.

7. Soyka LA, Fairfield WP, Klibanski A. Hormonal determinants and disorders of peak bone mass. J Clin Endocrinol Metab 2000;85(11):3951-63

8. Weaver CM, Peacoch M, Martin BR, Plawecki K, McCabe GP. Calcium retention estimated for indicator of skeletal status in adolescent girls and adult women. Am J Clin Nutr 1995;64:67-70.

9. Eastell R. Pathogenesis of postmenopausal osteoporosis. In: Favus MJ, ed. Primer on the Metabolic Bone Diseases and Disorders of Mineral Metabolism. 4th edition. Philadelphia: Lippincott Williams \& Wilkins, 1999. pp. 260-2.

10. Riggs BL, Melton $3^{\text {rd }}$ LJ. Involutional osteoporosis. N Engl J Med 1986;314:1676-86.

11. Melton 3rd LJ, Kan SH, Frye MA, Wahner HW, O'Fallon WM, Riggs BL. Epidemiology of vertebral fractures in women. Am J Epidemiol 1989;129:1000-11.

12. Christiansen C. Postmenopausal bone loss and the risk of osteoporosis. Osteoporos Int 1994;4:47-51.

13. Harris S, Dallal GE, Dawson Hughes B. Influence of body weight on rates of change in bone density of the spine, hip and radius in postmenopausal women. Calcif Tissue Int 1992;50:19-23.

14. Albala C, Yanez M, Devoto E, Sostin C, Zeballos L, Santos JL. Obesity as a protective factor for postmenopausal osteoporosis Int J Obes Relat Metab Disord 1996;20(11):102732.

15. Michel BA, Bloch DA, Fries JF. Weight-bearing exercise, overexercise and lumbar bone mineral density over age 50 years. Arch Intern Med 1989;149:2325-9.

16. Nawata H, Tanaka S, Takayanagi R, Sakai Y, Yanese T, Ikuyamas $S$ et al. Aromatase in bone cell: association with osteoporosis in postmenopausal women. J Steroid Biochem Mol Biol 1995;53(1-6):165-74.

17. Suzuki N, Yano T, Nakazawa N. A possible role of estrone produced in adipose tissue in modulating postmenopausal bone density. Maturitas 1995;22:9-12.

18. Thomas T, Gori F, Khosla S, Jensen MD, Burguera B, Riggs $B L$. Leptin acts on human marrow stromal cells to enhance differentiation to osteoblasts and to inhibit differentiation to adipocytes. Endocrinology 1999;140:1630-8.

19. Goulding A, Taylor RW. Plasma leptin values in relation to bone mass density and to dynamic biochemical markers of resorption and formation in postmenopausal women. Calcif Tissue Int 1998;63:456-8.
20. Haffner SM, Bauer RL. The association of obesity and glucose and insulin concentration with bone density in premenopausal and postmenopausal women. Metabolism 1993;42:735-8.

21. World Health Organization. Physical status: the use and interpretation of anthropometry. Report of a WHO expert committee. Technical report series no. 854. Geneva: WHO, 1995.

22. Garrow JS, Webster J. Quetelet's index (W/H2) as a measure of fatness. Int J Obesity 1985;9:147-53.

23. Introduction to understand bone densitometry. The International Society for Clinical Densitometry. Disponível em: <http://www.iscd.org>. Acessado em Novembro de 2006.

24. Hla MM, Davis HM, Ross PD, Yates AJ, Wasnich RD, Ravn P et al. Relation between body composition and biochemical markers of bone turnover among early postmenopausal women. J Clin Densitom 2000;3(4):365-71.

25. Delmas PD. Biochemical markers for the assessment of bone turnover. In: Osteoporosis: etiology, diagnosis and management. $2^{\text {nd }}$ edition. Philadelphia: Lippincott-Raven, 1995. pp. 319-33.

26. Riis BJ. The role of bone turnover in the pathophysiology of osteoporosis. Br J Obstet Gynaecol 1996;103:9-15.

27. Ribot C, Tremollieres F, Pouilles JM. The effect of obesity on postmenopausal bone loss and the risk of osteoporosis. Adv Nutr Res 1994;9:257-71.

28. Rico H, Arribas I, Casanova FJ, Duce AM, Hernandez ER, Cortes-Prieto J. Bone mass, bone metabolism, gonadal status and body mass index. Osteoporos Int 2002;13(5):379-87.

29. Blain H, Vuillemin A, Guillemin F, Durant R, Hanesse B, de Talance N, et al. Serum Leptin level is a predictor of bone mineral density in postmenopausal women. J Clin Endocrinol Metabol 2002;87:1030-5.

30. Reid IR. Relationships among body mass, its components, and bone. Bone 2002;31(5):547-55.

31. Thomas T, Burguera B, Melton LJ, Atkinson EJ, O'Fallon WM, Riggs $B L$, et al. Role of serum Leptin, insulin and estrogen levels as potential mediators of the relationship between fat mass and bone mineral density in men versus women. Bone 2001;29:114-20.

32. Reid IR, Ames R, Evans MC, Sharpe S, Gamble G, France JT, et al. Determinants of total body and regional bone mineral density in normal postmenopausal women - a key role for fat mass. J Clin Endocrinol Metab 1992;75:45-51.

33. Haffner SM, Bauer RL. Excess androgenicity only partially explains the relationship between obesity and bone density in premenopausal women. Inter J Obes 1992;16:869-74.

34. Bronsky J, Prusa R. Amylin fasting plasma levels are decreased in patients with osteoporosis. Osteoporos Int 2004; 15(3):243-7

35. Meli R, Pacilio M, Raso GM, Esposito E, Coppola A, Nasti A, et al. Estrogen and raloxifene modulate Leptin and its receptor in hypothalamus and adipose tissue from ovariectomized rats. Endocrinology 2004; 145(7):3115-21.

36. Nagy Z, Speer G, Takacs I, Bajnok E, Lakatos P. Serum Leptin levels and bone mineral density in postmenopausal women. Bone 2001;28:S284 [abstract].

37. Morberg CM, Tetens I, Black E, Toubro S, Soerensen TIA, Pedersen $\mathrm{O}$, et al. Leptin and bone mineral density: A crosssectional study in obese and non obese men. J Clin Endocrinol Metabol 2003;88(12):5795-800

38. Cleland WH, Mendelson CR, Simpson ER. Effects of aging and obesity on aromatase activity of human adipose cells. $\mathbf{J}$ Clin Endoc Metab 1985;60(1):174-7.

39. Garnero P, Sornay-Rendu E, Claustrat B, Delmas PD. Biochemical markers of bone turnover, endogenous hormones and the risk of fractures in postmenopausal women: the OFELY study. J Bone Miner Res 2000;15:1526-36.

40. Cifuentes $M$, Johnson MA, Lewis RD, Heymsfield SB, Chowdhury HA, Modlesky CM, et al. Bone turnover and body weight relationship differ in normal-weight compared with heavier postmenopausal women. Osteoporos Int 2003;14(2):116-22.

41. Papakitsou EF, Margioris AN, Dretakis KE, Trovas G, Zoras U, Lyritis $\mathrm{G}$, et al. Body mass index (BMI) and parameters of bone formation and resorption in postmenopausal women. Maturitas 2004;47:185-93. 
42. Hla MM, Davis HM, Ross PD, Wasnich RD, Yates AJ, Ravn P, et al. A multicenter study of the influence of fat and lean mass on bone mineral content: Evidence for differences in their relative influence at major fracture sites. Am J Clin Nutr 1996;64:354-60.

43. Rand T, Schneider B, Grampp S, Wunderbaldinger P, Migsits $\mathrm{H}$, Imhof $\mathrm{H}$. Influence of osteophytic size on bone mineral density measured by dual X-ray absorptiometry. Acta Radiol 1997;38(2):210-3.

44. Frost HM. Obesity, and bone strength and "mass": a tutorial based on insights from a new paradigm. Bone 1997;21(3):211-4.

45. Becker C. Clinical evaluation for osteoporosis. Clinics Geriatr Med 2003;19(2):299-320.

46. McClung MR. The relationship between bone mineral density and fracture risk. Curr Osteoporos Rep 2005;3(2):57-63.
47. Ahlborg HG, Olof Johnell O, Turner CH, Rannevik G, Karlsson MK. Bone loss and bone size after menopause. N Eng J Med 2003;349(4):327-34.

48. Szejnfeld VL, Atra E, Bacarat EC. Bone density in white Brazilian women: rapid loss in the time around menopause. Calcif Tissue Int 1995:56:186-91.

\section{Endereço para correspondência:}

Henyse Gomes Valente da Silva

Rua Josué de Castro 39

22793-265 Rio de Janeiro, RJ

E-mail: henysevalente@hotmail.com 